\title{
MAKNA KERJA BAGI PENGUSAHA KECIL MUSLIM DI TENGAH PERKEMBANGAN BISNIS KULINER
}

\author{
Muhammad Djakfar \\ (Fakultas Ekonomi UIN Maulana Malik Ibrahim Malang, \\ Jalan Gajayana No 50 Malang, Email: mdjakfar@yahoo.co.id)
}

\begin{abstract}
Abstrak:
Kehadiran usaha menengah kecil (UMK) jelas merupakan sebuah keniscayaan untuk menyangga kekuatan ekonomi dalam sebuah negara, tanpa kecuali bagi Indonesia. Betapa banyak tenaga kerja yang terserap unit usaha ini sehingga keberadaannya menjadi stabilisator dan dinamisator, baik di saat perekonomian negara dalam kondisi stabil maupun emergensi. Penelitian ini ingin memahami makna kerja bagi pengusaha kecil Muslim dan apa saja motif mereka dalam membangun usaha. Selain juga ingin memahami bagaimana strategi pemasaran dan pembinaan sumber daya manusia yang dilakukan oleh mereka. Penelitian menggunakan pendekatan kualitatif, tepatnya fenomenologi. Sedangkan teknik penggalian data digunakan interview mendalam, observasi terlibat, dan dokumentasi. Hasil penelitian menunjukkan bahwa motif mereka dalam membangun usaha adalah karena faktor spiritualitas dan hobbi. Strategi pemasaran dilakukan melalui iklan, keikutsertaan dalam forum ilmiah, dan pembukaan cabang baru. Pembinaan karyawan dilakukan dengan perlakuan secara manusiawi dengan akhlak terpuji, sedangkan kerja bagi pelaku dimaknai sebagai media ibadah, ekonomi, silaturrahim, pendidikan, dan dakwah.
\end{abstract}

Abstract:
The emergence of small business enterprises has shown an
inevitability to support economic power in a country, even in
Indonesia. There are so many labors that are included in this small
business enterprise so that their existence becomes stabilizer and
dynamic maker, either in a stable or emergency condition of the
country's economy. This research is trying to understand the meaning
of working to Moslem's small business enterprises and to know their
motives in developing their business and also their marketing
management and their human resource construction that they have
done. This research uses qualitative approach, phenomenology for

al-Ihkâm Vol.10 No.2 Desember 2015

DOI: http://dx.doi.org/10.19105/ihkam.v10i2.736 
Muhammad Djakfar

exact. While the data taken from deep interview, participant observation, and documentation. The result shows that the motives of developing their business is because of spiritual factor and also hobby. The marketing strategy is done through advertising, joining the scientific forum, and opening new branches. The employees' construction is done humanely and with good attitude, while the meaning of "working" to the workers is as a means of worship, economy, relationship, education, and $d a^{\prime} w a h$.

\section{Key Words:}

Makna Kerja, Usaha Kecil Muslim, Strategi Pemasaran Pembinaan, Sumber Daya Manusia

\section{Pendahuluan}

Usaha mikro, kecil, dan menengah (UMKM) merupakan garda terdepan perekonomian di banyak negara berkembang termasuk Indonesia. UMKM sekaligus menjadi wadah strategis sebagai penyedia tenaga kerja mandiri yang bebas dari ketergantungan kepada pihak lain. Indonesia saat ini masih terus berupaya meningkatkan perekonomian demi peningkatan taraf kemakmuran rakyatnya.

Menurut data Kementerian Koperasi dan Usaha Kecil Menengah (Kemenkop dan UKM), saat ini jumlah UMKM di Indonesia bertambah. Kendati ada yang tidak sedikit yang 'mati suri' karena keterbatasan permodalan atau sumber daya manusia (human resource). ${ }^{1}$ Menurut data Kemenkop dan UKM, per Juni 2013, terdapat

1 Periksa, "Perkuat UMKM Hadapi Komunitas ASEAN.", dalam Republika, 9 September 2013. Sebagaimana kita ketahui bahwa aktivitas pokok dari UMKM adalah kewirausahaan. Karena itu aktivitas kewirausahaan bagaimanapun memegang peranan sentral dalam kemajuan ekonomi sebuah negara, baik negara maju (developed countries) maupun berkembang (developing countries), tanpa kecuali Indonesia. Menurut PBB, suatu negara akan mampu membangun ekonominya dengan maksimal apabila negara tersebut memiliki wirausahawan sebanyak $2 \%$ dari jumlah penduduknya. Jepang misalnya memiliki $2 \%$ wirausahawan tingkat sedang dan 20\% tingkat kecil (small) dari jumlah populasi yang ada. Lihat Heidjrachman R. Pandojo, Wiraswasta Indonesia, (Yogyakarta: BPFE, 1982), 12. Selanjutnya lihat dan bandingkan dengan H.Buchari Alma, Kewirausahaan, (Bandung: Penerbit Alfabeta, 2002), 5. Sehingga dengan demikian, Jepang sukses sebagai negara maju di bidang ekonomi, setara dengan negara-negara maju, seperti Amerika maupun negara-negara 
55,2 juta UMKM, atau 99,98 persen dari total unit usaha di Indonesia yang dapat menyerap 101, 72 juta tenaga kerja atau setara dengan 97,3 persen dari keseluruhan tenaga kerja Indonesia. ${ }^{2}$ Disampaikan bahwa UMKM mampu menyumbang 57,12 persen dari produk domestik bruto (PDB), yakni sekitar delapan ribu dua ratus triliun rupiah. Sampai dengan Juni 2013 tercatat sebanyak 194.275 koperasi. Naik secara signifikan dari akhir ahun 2012, yakni 155 ribu koperasi. ${ }^{3}$ Keberadaan koperasi signifikan dalam menopang permodalan UMKM.

Indonesia, sebagai salah satu dari negara-negara berkembang (developing countries), selayaknya perlu memberdayakan UMKM secara sungguh-sungguh dan terprogram. ${ }^{4}$ Karena itu kehadiran Kementerian Koperasi dan Usaha Kecil dan Menengah, di Indonesia merupakan sinyal positif konstruktif kehadiran pemerintah yang secara nyata merespons kebutuhan dan kehadiran UMKM agar menjadi sokoguru penggerak perekonomian di tanah air di masa kini dan akan datang. ${ }^{5}$

Menurut Mudrajat Kuncoro, pengamat ekonomi dan bisnis dari Universitas Gajah Mada Yogyakarta, untuk mendukung pertumbuhan UKM agar dapat menekan angka pengangguran perlu

maju lain di kawasan Eropa. Bahkan, akhir-akhir ini, di kawasan Asia, kemajuan bidang ekonomi itu diikuti pula oleh Cina dan India. Untuk selanjutnya, dalam kaitan dengan apakah kewirausahaan itu, baca antara lain, William D. Bygrave, The Portable MBA Entrepreneurship (New York: John Willey \& Sons, Inc, 1995), David Deakins, Entrepreneurship and Small Firms (London: The McGrew-Hill Companies, 1996), Robert D. Hisrich and Michael P. Peters, Entrepreneurship (Tokyo, Japan: Toppan Company, Ltd, 1992), Geoffry G. Meredith, et.al., The Practice of Entrepreneurship (Begeva: International Labour Organization, 1986), dan Thomas W. Zimmerer and Norman M. Scarborough, Essentials of Entrepreneurship and Small Business Management, 2nd edition (New Jersy: Printice Hall, inc Upper Sadle River, 1998).

2 Perkuat UMKM Hadapi Komunitas ASEAN, Republika, 9 September 2013

${ }^{3}$ Republika, 9 September 2013

4 Lihat dan bandingkan dengan Hermanto Siregar, "Prakata", dalam Gatut Susanta dan M. Azrin Syamsuddin, Cara Mudah Mendirikan \& Mengelola UMKM (Jakarta: Raih Asa Sukses, 2009), 3

5 Tekad Pemerintah untuk terus memberdayakan UMKM, juga terlihat pada saat Presiden SBY memperjuangkan agar masalah UMKM ini masuk agenda pembicaraan di pertemuan APEC di Bali tanggal 7-8 Oktober 2013. Termasuk juga diperjuangkan pula pada pertemuan ASEAN ke 23 di Brunei Darussalam, 9 Oktober 2013. Lihat, "APEC Selesai, SBY Hadiri KTT ASEAN," dalam Jawa Pos, 10 Oktober 2013. 
meminta dukungan Badan Usaha Milik Negara (BUMN). "Jadikan UKM sebagai mitra berprogress, tidak hanya sekadar objek CSR," kata Mudrajat. 6

Bentuk atau wujud dukungan itu antara lain yang berkaitan dengan masalah bina manajemen, bina etika, bina etos atau spirit berwirausaha. Atau dukungan bimbingan tentang bagaimana cara memperoleh modal, mengajukan izin usaha, penguasaan teknologi informasi dan komunikasi (TIK), agar dapat meningkatkan daya saing Indonesia di pasar global terutama dalam menghadapi pasar bebas ASEAN yang sedianya akan diawali pada tahun 2015.7

Dalam kaitan ini, menurut World Economic Forum (WEF) dalam the Global Competitiveness Report 2013-2014, saat ini indeks daya saing Indonesia mengalami loncatan yang masif. Pertanyaannya adalah apakah di dalamnya termasuk kemampuan UMKM? Jika demikian, seberapa signifikankah kenaikan kemampuan itu sehingga Indonesia yang sebelumnya hanya menduduki posisi 50, berhasil menempati peringkat 38 dari 148 negara?8 Jika dibandingkan dengan sesama negara-negara ASEAN, Indonesia baru menduduki posisi kelima, di bawah Singapura (urutan 2), Malaysia (urutan 24), Brunei Darussalam (urutan 26), dan Thailand (urutan 37). ${ }^{9}$

Peningkatan daya saing UMKM itu telah diperjelas oleh Menteri Koperasi dan Usaha Kecil Menengah era Presiden SBY, Syariefuddin Hasan. Dengan tegas ia menyatakan bahwa UKM Indonesia di tingkat global semakin kuat sehingga berdampak positif bagi kesejahteraan rakyat. ${ }^{10}$ Untuk mendukung pernyataannya ini, Menteri Koperasi mengemukakan data pendapatan perkapita yang telah mencapai 3.797 dolar AS. Bahkan tahun 2014, ia memprediksi pendapatan per kapita di Indonesia akan lebih dari 4.500 dolar AS dengan tingkat pertumbuhan sekitar tujuh persen. ${ }^{11}$

6 Periksa, "UKM Perkuat Ekonomi Nasional," dalam Republika, 19 September 2013.

7 Lihat, "Strategi Hadapi Pasar Bebas ASEAN," dalam Republika, 19 September 2013. Selanjutnya lihat pula, "Perkuat UMKM Hadapi Komunitas Ekonomi ASEAN," dalam Republika, 9 September 2013.

8 Lihat, "Daya Saing Indonesia Naik, Bisnis Membaik," dalam Republika, 5 September 2013. Selanjutnya lihat pula, Jawa Pos, 5 September 2013.

${ }_{9}^{9}$ Republika, 5 September 2013.

10 Republika, 5 September 2013.

11 Republika, 5 September 2013 
Karena secara sosiologis populasi penduduk Indonesia yang berjumlah sekitar 242 juta orang dan sekitar 87,5 \% (sekitar 210 juta) adalah pemeluk Islam maka, niscaya kegiatan UMKM banyak digerakkan oleh pengusaha Muslim yang tersebar di seluruh penjuru tanah air. Salah satu kegiatan UMKM yang paling diminati pelaku usaha Muslim adalah usaha kuliner.

Di kota Malang, para pelaku usaha Muslim tersebut banyak yang terjun ke dunia usaha kuliner. Di antaranya adalah usaha bubur ayam Tasikmalaya "Abah Odil" di kawasan bisnis baru SoekarnoHatta Malang. Pemiliknya yang dikenal dengan panggilan pak Ate (lengkapnya: Ate Rushendi) adalah seorang insinyur pertekstilan yang pernah bekerja di perusahaan benang milik asing dan sarung Wadimor. Karena merasa kurang nyaman, pak Ate memutuskan keluar dan terjun ke dunia wirausaha mandiri. Pak Ate merupakan pribadi Muslim yang taat. Dalam mengembangkan usaha bubur ayamnya,ia mempekerjakan para pemuda yang berlatarbelakang santri.

Berdasar beberapa faktor tersebut, usaha bubur ayam Tasikmalaya "Abah Odil" ini dipilih sebagai objek penelitian dengan tujuan untuk memahami bagaimana konteks atau latar belakang usaha; bagaimana bekerja dan usaha dimaknai sehingga mereka memiliki etos kerja yang tinggi, kreatif dan inovatif. Juga bagaimana kiat-kiat Pak Ate mengembangkan usaha melalui strategi pemasaran dan pengembangan sumber daya manusia pelaksananya.

Penelitian ini bertujuan untuk menggali dan memahami lebih mendalam tentang latar belakang atau yang mejadi dasar pertimbangan berdirinya usaha bubur ayam Tasikmalaya "Abah Odil." Bagaimana strategi pemasaran dan pembinaan sumber daya manusia pelakunya. Makna kerja dalam mengembangkan usaha sehingga mereka mempunyai etos kerja yang tinggi, kreatif dan inovatif. Pemahaman akan makna di sini dimaksudkan terkait dengan mind (pattern of thinking) si pelaku (aktor) serta motif tujuan (in order to motives) dan motif sebab (bacause motives) dalam melakukan aktivitas (tindakannya).

Banyak kegunaan atau manfaat yang dapat dipetik dari penelitian ini. Pertama, bagi pemerintah, khususnya Kementerian Koperasi dan UKM. Hasil penelitian ini diharapkan akan menjadi bahan evaluasi atas kebijakan yang selama ini telah dilakukan. Kedua, 
bagi dunia perguruan tinggi, dalam kapasitasnya sebagai institusi akademik. Hasilnya diharapkan dapat memperkaya wawasan tentang UMKM dan pengembangan ekonomi kreatif serta dapat membantu memecahkan problem-problem yang membelitnya melalui konsepkonsep akademik-ilmiah. Hal ini akan berguna untuk mengembangkan teori atau model pembinaan dan pengembangan usaha kecil di Indonesia di masa yang akan datang. Ketiga, bagi pegiat usaha kecil. Diharapkan hasil penelitian ini dapat dijadikan pola dalam melakukan bisnis baru yang prospektif, terutama usaha kuliner yang saat ini sedang tumbuh berkembang di banyak tempat.

\section{Kajian Teori}

\section{Teori tentang Etos Kerja}

Sementara ini, di kalangan Muslim, dalam kaitan dengan etos entrepreneurship, muncul imej steriotipikal rendahnya gairah kegiatan ekonomi, dan rendahnya kualitas kapitalisme. ${ }^{12}$ Ini menunjukkan melimpahnya sumber daya alam (natural resources) di negeri Muslim yang belum tergarap secara maksimal, justru akan semakin menunjukkan lemahnya etos kewirausahaan di kalangan masyarakat Muslim. ${ }^{13}$

Padahal sejatinya ada relasi antara agama dengan etos kerja. Dalam tesisnya, Max Weber, sosiolog dan political economist asal Jerman, menyatakan tidak seperti Protestan, khususnya dari sekte Calvinis puritan, bahwa Islam tidak mempunyai afinitas teologis dengan pengembangan kapitalisme. ${ }^{14}$ Memang dilihat dari pendapat tersebut, seakan-akan Weber melecehkan, bagaimana sejatinya pengaruh ajaran agama-agama lain di dunia terhadap motivasi kerja umatnya, khususnya Islam.

Dalam Islam, banyak terminologi al-Qur'an yang dapat dijadikan sumber dorongan untuk bekerja atau berusaha (theological underpinnings of Islam on work or entrepreneurship) yang perlu digali. Terminologi tentang rizq misalnya, yang sangat populer dalam

\footnotetext{
12 Muhammad Djakfar, Anatomi Perilaku Bisnis Dialektika Etika dengan Realitas, (Malang: UIN-Malang Press, 2009), 31

${ }_{13}$ Djakfar, Anatomi Perilaku, 31

14 Max Weber, Etika Protestan dan Semangat Kapitalisme, Ter. Yusup Priasudirja, (Jakarta: Pustaka Prometha, 2003).
} 
kehidupan sehari-hari, erat kaitannya dengan "etos kerja."15 Menurut Dawam Rahardjo, tentang rizq dengan segala variasinya, disebutkan sebanyak 112 kali dalam 41 surat. ${ }^{16}$ Sedangkan menurut Muhammad Fuad Abd al-Baqi dalam kamusnya $M u^{\prime}$ jam al-Mufahras li al-Alfâzh alQur'ân al-Karîm, menyebutkan 123 kata rizq dengan segala variasinya. Pada umumnya kata rizq dikaitkan dengan kata lain, seperti 'amal, maisah, tijârah, barakah, infaq, shadaqah, dan ribâ.

Dalam kaitan dengan 'amal misalnya, menurut Mustaq Ahmad, al-Qur'an menyebutkan 360 ayat yang membicarakan tentang amal, dan 109 yang membicarakan tentang fi'il yakni dua kata yang sama-sama bermakna kerja dan aksi. ${ }^{17}$ Kerja dan amal, dalam Islam, akan menentukan bagaimana posisi seseorang dalam kehidupan, sebagaimana firman-Nya: "Dan tiap-tiap orang memperoleh derajat dengan apa yang dikerjakannya. Dan Tuhanmu tidak lengah dari apa yang mereka kerjakan."18 Bahkan lebih jauh dari itu, al-Qur'an menjanjikan pahala yang berlimpah bagi orang yang bekerja untuk meningkatkan kualitas dan kuantitas kerjanya, "Bagi orang-orang yang berbuat kebaikan di antara mereka dan yang bertakwa ada pahala yang besar."19

Itulah ajaran Islam sebagai sumber motivasi yang sangat mendorong umatnya agar bekerja keras sebagaimana yang dipraktikkan langsung oleh Rasulullah saw. Dengan demikian sejatinya bekerja menurut Islam merupakan perintah agama yang wajib dilakukan oleh setiap Muslim dengan pahala yang melimpah.

\section{Konsep Kewirausahaan}

Zimmer sebagaimana yang dikutip Muh. Yunus mendefinisikan entrepreneur sebagai seseorang yang menciptakan bisnis baru dengan mengambil risiko dan ketidakpastian demi mencapai keuntungan dan pertumbuhan bisnis dengan cara

\footnotetext{
15 Effendy, Pertumbuhan Etos, 198

${ }_{16}$ M. Dawam Rahardjo, Ensiklopedi Al-Qur'an: Tafsir Sosial Berdasarkan Konsep-konsep Kunci, (Jakarta: Paramadina, 1996), 378

17 Dalam Mustaq Ahmad, Etika Bisnis dalam Islam, Terj. Samson Rahman, (Jakarta: Pustaka Al-Kautsar, 2001), 11

18 QS. al-An'âm 6:132

19 QS. Ali `Imrân 3:172
} 
mengidentifikasi peluang dan menggabungkan sumber daya yang diperlukan untuk mendirikannya. ${ }^{20}$

Timmons dan Mc Celland sebagaimana dikutip Suryana menyatakan, wirausahawan yang sukses memiliki karakteristik: Commitment and determination, desire for responsibility, opportunity obsession, tolerance for risk, ambiguity, and uncertainty, self confidence, creativity and flexibility, disire for immediate feedback, high level of energy, motivation to excel, orientation to the future, willingness to learn from failure, and leadership ability. ${ }^{21}$

Buchari Alma menyebutkan beberapa karakteristik yang perlu dimiliki oleh pelaku usaha Muslim yakni bertakwa, tawakkal, zikir, bersyukur, jujur, niat suci dan ibadah, azam dan bangun lebih pagi, toleran, berzakat dan berinfak, dan melakukan silaturahim. ${ }^{22}$ Ada pun pendapat lain tentang karakteristik pelaku usaha Muslim antara lain tidak takut akan risiko yang akan terjadi, memiliki spirit iqra', pantang berputus asa, sabar dalam menjalani, menghargai proses, dan tidak boros. ${ }^{23}$ Selanjutnya bertolak dari beberapa karakter tersebut pada akhirnya dapat dipetakan berbagai tipe karakter wirausaha, yakni wirausaha yang memiliki inisiatif, yang mengorganisir mekanis sosial dan ekonomi untuk menghasilkan sesuatu, dan yang terakhir wirausaha yang menerima risiko atau kegagalan. ${ }^{24}$

Dalam kaitan dengan masalah usaha kecil ini telah lahir Undang-Undang Republik Indonesia Nomor 20 Tahun 2008 tentang Usaha Mikro, Kecil, dan Menengah. Di dalam ketentuan umum Pasal 1 undang-undang ini dikatakan usaha mikro adalah "usaha produktif milik perorangan dan/atau badan usaha perorangan yang memenuhi kreteria usaha mikro sebagaimana diatur dalam undang-undang ini." 25 Sedangkan yang dimaksud usaha kecil, adalah "usaha ekonomi

${ }^{20}$ Muh. Yunus, Islam E Kewirausahaan Inovatif (Malang: UIN Malang Press, 2008), 27

21 Suryana, Kewirausahaan Kiat dan Proses Menuju Sukses, (Jakarta: Salemba Empat, 2013), 27

22 Alma, Kewirausahaan, 21

23 Siti Najma, Bisnis Syariah dari Nol Langkah Jitu Menuju Kaya, Penuh Berkah dan Bermakna (Jakarta: Hikmah, 2008), 49

${ }^{24}$ Alma, Kewirausahaan, 24-25

25 Periksa, Undang-Undang Republik Indonesia Nomor 20 Tahun 2008 tentang Usaha Mikro, Kecil, dan Menengah. 
produktif yang berdiri sendiri, yang dilakukan oleh orang perorangan atau dan usaha yang bukan merupakan anak perusahaan atau bukan cabang perusahaan yang dimiliki, dikuasai, atau menjadi bagian baik langsung maupun tidak langsung dari usaha menengah atau usaha besar yang memenuhi kriteria usaha kecil sebagaimana dimaksud dalam undang-undang ini." Hanya saja dalam praktik seringkali jenis usaha ini dikaitkan dengan bisnis ala rakyat kecil atau wong cilik yang tidak jarang pula akhirnya berkembang menjadi perusahaan yang maju. ${ }^{26}$

Data BPS dan Kementerian Koperasi dan UKM menunjukkan usaha kecil di Indonesia sekitar 99\%.27 Dan dalam hal ini pemerintah sangat intens dan serius dalam memberikan perhatian, sekaligus pembinaan dan pengembangan terhadap usaha ini.

Pandangan Islam terhadap kewirausahaan jelas tidak perlu disangsikan lagi, karena bidang ini telah dipraktikkan langsung oleh Rasulullah saw selama kurang lebih 25 tahun sejak beliau belum membina keluarga. Melebihi durasi misi nubuwahnya yang diperkirakan sekitar 23 tahun. ${ }^{28}$

Untuk selanjutnya, bagaimana konkretnya sifat-siafat dasar dalam prophetic values of business and management yang dicontohkan oleh Rasulullah saw untuk mengembangkan sektor riil (wirausaha), antara lain adalah sifat siddîq (jujur), amanah (terpercaya, bertanggung jawab, transparan, tepat waktu), fathanah (memiliki pengetahuan luas), tabligh (komunikatif), dan syaja'ah (berani). ${ }^{29}$ Pendapat lain menyatakan bahwa Nabi Muhammad saw sebagai model entrepreneur ideal mempunyai karakteristik: adil, fair dan jujur dalam

${ }^{26}$ Gatut Susanta dan M. Azrin Syamsuddin, Cara Mudah Mendirikan dan Mengelola UMKM (Depok: Penerbit Raih Asa Sukses, 2009), 6

27 Susanta dan Syamsuddin, Cara Mudah

28 Dalam kaitan dengan bagaimana praktik wirausaha Rasulullah saw, silakan baca Muhammad Djakfar, Teologi Ekonomi Membumikan Titah Langit di Ranah Bisnis, (Malang: UIN Maliki Press, 2010); Muhammad Djakfar, Etika Bisnis: Menangkap Spirit Ajaran Langit dan Pesan Moral Ajaran Bumi, (Depok-Bogor: Penebar Plus, 2012), Muhammad Syafii Antonio, Muhammad saw the Super Leader Super Manager, (Jakarta: Prophetic Leadership and Management Centre, 2007) dan Afzalurrahman, Muhammad sebagai Seorang Pedagang, Terj. Dewi Nurjulianti, dkk., (Penerbit Yayasan Swarna Bhumy, 1997)

29 Muhammad Syafii Antonio, "Prophetic Values of Business and Management," dalam Republika, Juni 2002 
bekerjasama dan bertransaksi, berorientasi pada manfaat dunia dan akhirat, amanah, zero defect minded dalam melayani, leading by example, setiap perilakunya adalah nilai, visionaris, hidup sederhana, dan memiliki kecerdasan spiritual tiada tara. ${ }^{30}$

\section{Pemasaran dan Sumber Daya Manusia}

Dalam kaitan dengan pemasaran ini dapat dikemukakan empat karakter syariah marketing, yakni teistis (rabbaniyyah), etis (akhlâqiyyah), realistis (waqi'iyyah), dan humanistis (insâniyyah). Teistis dimaksudkan bahwa seorang syariah marketer meyakini bahwa hukum-hukum syariat yang teistis adalah hukum yang paling adil, paling sempurna, paling selaras dengan segala bentuk kebaikan, mewujudkan kebenaran dan kemaslahatan, dan paling dapat mencegah kerusakan dan kebatilan. ${ }^{31}$ Sedangkan etis dimasudkan seorang syariah marketer akan sangat mengedepankan nilai akhlak dalam segala aktivitasnya.

Adapun realistis, maksudnya, seorang syariah marketer harus bersifat fleksibel, sebagaimana fleksibelnya ajaran syariah itu sendiri yang selalu sesuai dengan situasi dan kondisi secara riil. Selain juga harus bersikap humanistis, dalam arti menghargai hak dan harkat kemanusiaan, bukan manusia yang serakah yang menghalalkan segala cara untuk meraih keuntungan. 32

Selanjutnya dalam kaitan dengan masalah pembinaan sumber daya manusia kita dapat mengacu pada pendapat Yusuf al-Qardlawi yang mengemukakan empat karakeristik ekonomi Islam, yaitu uluhiyah, insâniyah, akhlâqiyah, dan washatiyah. ${ }^{33}$ Keempat karakter ini dapat dijadikan landasan untuk mengembangkan sumber daya manusia dalam sebuah perusahaan yang berbasiskan syariah.

30 Wasi Darmolono, Winning Mindset Potret Otak Entrepreneur Sejati, Berpikir Cemerlang Disaat Terbelit Hutang Merilis Bisnis Disaat Kondisi Kritis, (Yogyakarta: Nuha Qffset, 2009), 199

${ }^{31}$ Lihat, Hermawan Kartajaya dan Muhammad Syakir Sula, Syariah Marketing, Cet. 2, (Bandung: Penerbit Mizan, 2006), 28

32 Kartajaya dan Sula, Syariah, 35-38

${ }^{33}$ Lihat, Yusuf Qardhawi, Dawrul Qiyam wal Akhlaq fil Iqtishadil Islami (Kairo, Mesir: Maktabah Wahbah, 1415H/1995M) dan Muammad Djakfar, Agama, Etika, dan Ekonomi (Malang: UIN Malang Press, 2007), 83-107. Lihat pula Muhammad Djakfar, Teologi Ekonomi Membumikan Titah Langit di Ranah Bisnis, (Malang: UIN Maliki Press, 2010), 67-72 


\section{Metode Penelitian}

Objek penelitian ini adalah usaha bubur ayam Tasikmalaya "Abah Odil" yang berpusat di kawasan bisnis baru Jalan Soekarno Hatta, karena kawasan ini memang benar-benar baru dibanding kawasan lain yang terlebih dulu ada di kota Malang. Selain itu untuk terus mengembangkan sayap usahanya, usaha bubur ini sekarang membuka di kawasan lain. Antara lain di Karangploso dan kompleks perumahan Sawojajar. Khusus di Karangploso manajemen diserahkan kepada istri pemilik, sedangkan yang di kawasan Sawojajar statusnya independen yang dikelola oleh anaknya sendiri.

Sesuai dengan topik dan fokus yang telah dirumuskan, maka penelitian ini dapat dikategorikan ke dalam penelitian kualitatif. Secara metodologis dikenal beberapa teori sosial yang diasosiasikan dengan pendekatan kualitatif yakni teori-teori budaya, fenomenologi, etnometodologi, dan interaksi simbolik. ${ }^{34}$

Studi yang berupaya mengungkap makna tindakan subjektif, tidak mungkin bisa dicapai jika mengandalkan pendekatan positivisme atau kuantitatif yang general yang hanya dapat mengungkap kulitnya saja. ${ }^{35}$ Oleh sebab itu pendekatan fenomenologi dalam penelitian ini dianggap paling tepat. Asumsi pendekatan fenomenologi mengatakan bahwa bagi individu dalam melakukan interaksi antarsesama ada banyak cara dalam melakukan penafsiran pengalaman. Makna dari pengalaman itulah yang sejatinya membentuk realitas tindakan yang ditampakkan. ${ }^{36}$ Tegasnya, fenomenologi, berupaya memahami makna kejadian, gejala yang timbul, dan atau interaksi bagi individu pada sikon tertentu dalam kehidupan sehari-hari. Ia mengkaji masuk ke dalam dunia makna yang terkonsep dalam diri individu, kemudian diekspresikan dalam bentuk fenomena. ${ }^{37}$ Dengan kata lain, ia mencoba untuk menjawab pertanyaan, bagaimanakah struktur dan hakikat pengalaman

\footnotetext{
${ }^{34}$ Lihat, Burhan Bungin, Analisis Data Penelitian Kualitatif (Jakarta: PT RajaGrafindo Persada, 2003), 7

35 H. A. Fatchan, Metode Penelitian Kualitatif, (Surabaya: Jenggala Pustaka Utama, 2011), 129

36 Fatchan, Metode Penelitian, 30

37 Fatchan, Metode Penelitian, 30
} 
terhadap suatu gejala bagi individu. ${ }^{38}$ Dengan menggunakan pendekatan yang tepat secara metodologis, maka diharapkan dari penelitian ini diperoleh hasil yang akurat sesuai yang diharapkan.

Sedangkan jenis dan sumber data, sesuai dengan fokus dan tujuan yang telah dirumuskan, maka data yang dieksplorasi meliputi data primer maupun sekunder. Data primer digali dari sumber utama secara langsung, yaitu para pengelola usaha dan pelaku yang ikut terlibat secara langsung di dalamnya. Yakni bapak Ate selaku owner usaha bubur ayam Tasikmalaya "Abah Odil"dan para pembantunya (pramuniaga) yang terlibat dalam segala aktivitas. Tanpa kecuali data dari para pelanggan yang secara sukarela diminta untuk menjawab beberapa pertanyaan sesuai apa adanya tentang apa yang dilihat dan dirasakan selaku penikmat.

Tentu saja data ini digunakan untuk mendukung dan memperkuat data primer agar hasilnya lebih sempurna dan akurat. Sedangkan data sekunder diperoleh dari beberapa dokumen yang dianggap relevan yang dapat didapat selama penelitian ini berlangsung. Karena dalam kenyataan banyak dokumen yang bisa direkam di lokasi tempat berjualan usaha bubur ayam ini yang tidak perlu ditanyakan, namun seizinnya langsung bisa dicatat.

Adapun yang berkaitan dengan penggalian data digunakan motode interview mendalam (depth interview), observasi partisipan (participant obsevation), dan dokumenter. Ketiga metode ini tentu saja sangat urgen sekali di dalam melacak data yang dibutuhkan. Interview misalnya, digunakan untuk menggali data yang bertalian dengan apa yang melatarbelakangi dibukanya usaha bubur ayam Tasikmalaya. Atau untuk jelasnya, ingin memahmi pertanyaan mengapa usaha itu dilakukan, sekaligus mencari jawaban dalam upaya untuk memahami pemaknaan si pelaku itu sendiri terhadap kerja keras dalam membuka usaha selama ini. Selanjutnya, dieksplor pula apa makna keterlibatan para pramuniaga menurut pemahaman mereka sendiri yang selama ini telah banyak terlibat dalam

38 Fatchan, Metode Penelitian, 30. Baca pula, antara lain, George Ritzer, Sosiology: A Multiple Paradigm Science, Terj. Alimanda (Jakarta: Rajawali Press, 1992). Selanjutnya bandingkan dengan, Alfred Schutz, The Phenomenology of the Social World (America: Northwestern University, 1972). Baca pula, Mariasusi, Dhavamony, Fenomenologi Agama, Terj. A. Sudiaraja, dkk., (Yogyakarta: Penerbit Kanisius, 1995). 
manajemen pelaksanaan. Termasuk pula bagaimana pandangan para pelanggan dengan maksud untuk mendukung data utama.

Demikian pula yang berkaitan dengan masalah strategi pemasaran dan pembinaan sumber daya manusia (human resources) yang terlibat dalam pengelolaan dan operasional sebuah perusahaan. Karena kedua strategi ini jelas melekat pada manajemen sebuah perusahaan agar dapat terus berkembang sesuai yang direncanakan. Sebab itu data tentang keduanya digali melalui interview, di samping pula melalui observasi terlibat.

Selanjutnya berkaitan dengan metode observasi dan dokumentasi, tidak kalah pentingnya dalam menggali data yang dianggap relevan. Observasi digunakan untuk melihat langsung bagaimana kondisi para pelaku di dalam mengelola usaha dalam kesehariannya. Kesemuanya itu lebih tepat dilakukan melaui pengamatan langsung di situs penelitian. Karena itu peneliti bersama tim seringkali melakukan pengamatan langsung dan bahkan juga tidak jarang sekaligus memposisikan diri sebagai pelanggan sebagaimana pelanggan-pelanggan yang lain. Inilah yang dimaksud observasi terlibat, karena peneliti beserta tim memang secara fisik hadir di lokasi selama penelitian.

Sedangkan data-data tertulis atau terdokumentasi yang berkaitan dengan objek penelitian direkam dengan motode dokumentasi. Misalnya yang berkaitan dengan jumlah pelanggan setiap tahun. Selanjutnya yang perlu dipahami bahwa penggunaan ketiga metode tersebut selain untuk mengeksplor data yang relevan dengan masing-masing metode, juga untuk keperluan triangulasi agar data yag diperoleh benar-benar valid yang merupakan prasyarat keabsahan hasil penelitian sesuai yang diharapkan.

Sesuai dengan karakter penelitian kualitatif yang tidak menggunakan metode statistik sebagaimana lazimnya dalam pendekatan kuantitaif, maka data yang telah terkumpul dianalisis dengan menggunakan model interaktif seperti yang dikembangkan oleh Miles and Huberman. ${ }^{39}$ Dengan metode ini pemaknaan tentang etos kerja dalam membangun usaha bubur ayam akan mudah dan

\footnotetext{
39 A. Michael Huberman dan Matthew B. Miles, "Data Management and Analysis Methods," dalam Norman K, Denzin dan Yvonna S. L:incoln (ed), Handbook of Qualitative Research, (Thousand Oaks: Sage, 1994), 10
} 
jelas untuk dipahami. Pemaknaan itu hampir mustahil untuk dapat digambarkan, terlebih lagi dipahami, jika sekiranya dilakukan dengan pendekatan kuantitatif yang hanya menyajikan angka-angka yang tanpa makna.

Dalam hal ini analisis data berlangsung secara simultan bersamaan dengan proses pengumpulan data dengan melalui berbagai tahapan yang berawal dari penggalian data, dilanjutkan dengan disply dan reduksi data. Sampai akhirnya diakhiri dengan menarik kesimpulan atau verifikasi.

\section{Hasil Penelitian dan Pembahasan Profil Usaha: Gambaran Umum}

Keberadaan usaha bubur ayam istimewa Tasikmalaya "Abah Odil," tidak bisa lepas dari perintis atau pendirinya, yakni Ate Ruhendi yang berasal dari Tasikmalaya Jawa Barat. Ia tergolong pengusaha intelek yang menyandang sarjana muda (Bachellor of Science) di bidang pertekstilan yang diperoleh dari sebuah perguruan tinggi swasta di kota Bandung.

Pada 1995, Ate pindah dari Tasikmalaya ke Malang. Selanjutnya pada 2004, ia memulai merintis usaha bubur ayam yang menjadi kesukaannya sejak usia remaja di kampung halamannya. Usaha tersebut diberi nama "Bubur Ayam Tasikmalaya Istimewa Abah Odil," yang akhirnya dikenal dengan nama "Abah Odil" saja. Nama "Abah Odil," menurut penjelasan Prasetya, Kamela, dan Yanti, ketiganya karyawan dan Ate sendiri, terinspirasi dari anak keempat Ate yang bernama Abdillah yang dipanggil Odil. Dengan kesepakatan bersama, maka nama tersebut diabadikan sebagai nama usahanya.

Semula, Ate berjualan dengan cara keliling, namun dengan semangatnya yang tinggi hingga saat ini (sudah berjalan selama 10 tahun), ia memiliki tujuh cabang. Yakni di Ruko Griyashanta Eksekutif MP-48, tepatnya, di Jl. Soekarno-Hatta yang sekarang menjadi pusat penjualan karena tempatnya yang sangat strategis secara bisnis. Selanjutnya, cabang Jl. Raya Candi Panggung (rumah tinggal), Sawojajar, Pujasera Universitas Brawijaya, Royal ATK, Karang Ploso, dan Landung Sari. Khusus cabang Sawojajar sekarang sudah berstatus independen karena cabang ini sudah dikelola secara mandiri oleh salah seorang anaknya. 
Usaha bubur ayam ini memiliki slogan "Rasa Bicara Sejak Suapan Pertama," yang asal mulanya berawal dari ketika Nurul Arifin, salah seorang kader Golkar berkeliling Kota Malang yang saat itu sempat singgah di tempat usaha Ate dan mencoba mencicipi bubur ayam sebagai menu utama. Secara spontan ia berkomentar, bahwa tokonya bagus dan menarik sejak suapan pertama setelah duduk dan menikmati bubur ayam. Dari itu, akhirnya Ate, kata Prasetyo, salah seorang karyawan, terinspirasi untuk membuat slogan itu yang dipampang di arena ruang utama penjualan.

Dari segi menu, usaha bubur Ate memiliki empat menu utama, dengan harga yang bervariasi. Yakni bubur ayam istimewa, bubur ayam spesial rempelo ati, bubur ayam super plus rempelo ati plus telor ayam kampung setengah matang, dan bubur ayam jumbo. Manurut Prasetyo, yang banyak diminati oleh pelanggan adalah bubur ayam istimewa dan bubur ayam spesial rempelo ati. Usaha ini berjualan mulai jam 06.00 pagi hingga jam 21.00 malam setiap hari, kecuali hari Sabtu dan Minggu tutup pada jam 17.00 sore hari.

Pada hari biasa, konsumen yang datang paling tidak 50 orang. Sedangkan pada hari-hari libur dan weekend bisa mencapai 100 orang, bahkan lebih. Konsumen sebagian besar berasal dari kalangan mahasiswa di Malang dan sebagian dari luar kota Malang. Salah satu alasan konsumen yang datang ke bubur ayam ini, menurut Prasetyo dan Ate, mereka mencari variasi lain untuk sarapan pagi karena bubur ayam Ate berbeda dengan yang lain dan rasanya enak plus gurih. Hal ini diakui sendiri oleh Syamsul Arifin, Anik dan Niswatun yang ketiganya secara kebetulan berprofesi sebagai dosen dan menjadi penggemar bubur ayam Abah Odil.

Dari segi omzet, pada hari biasa, sehari bisa mencapai 2 (dua) hingga 2,5 (dua setengah) juta rupiah, sedangkan pada akhir pekan bisa mencapai lebih dari itu. Itu pun belum terhitung omzet cabangcabang yang lain. Omzet tersebut menurut Prasetyo, setiap harinya langsung dipotong infak sebesar 2,5 persen, sehingga dengan demikian, Ate biasa berinfak antara dua atau tiga kali setiap harinya berdasarkan shift pada hari tersebut.

Suka duka yang dirasakan selama 10 tahun ini kata Ate, adalah lebih banyak sukanya. Dukanya adalah karena seringkali terjadi karyawan keluar masuk. Terkadang seminggu atau dua minggu saja yang bekerja. Namun demikian menurut menjelasan 
Kamela, abah selalu menerima siapa pun yang ingin bekerja disini secara full time atau pun part time (tanpa membedakan agama), karena beliau kembali pada visinya, yaitu untuk ibadah, menolong orang lain yang membutuhkan lapangan pekerjaan dan membukakan pintu rezeki bagi mereka

Adapun di antara tantangan yang harus dihadapi, kata Ate, di awal merintis usahanya, yaitu ada semacam stigma bahwa bisnis bubur ayam dianggap menjual makanan orang sakit. Tapi abah menurut Yanti, terus berusaha melawan kebiasaan orang Jawa Timuran dan selalu optimis sehingga akhirnya bubur ayam "Abah Odil," diterima oleh masyarakat. Tidak hanya stigma semacam itu yang dilawan oleh Ate, bahkan tempat berjualan pun apabila suasananya dianggap kurang Islami, dia selalu berusaha untuk memindahkan ke tempat lain. Sebagai contoh cabang yang berada di pujasera UB, tepatnya di samping MX Mall, karena dinilai tidak sesuai syariah, maka ada rencana cabang ini akan dipindah ke tempat lain yang dianggap lebih syariah.

\section{Motif Melakukan Usaha}

Hal-hal yang mendorong Ate melakukan bisnis adalah tercermin dari misinya, yaitu untuk beribadah dalam bentuk usaha guna memenuhi kebutuhan diri dan keluarganya. Ini merupakan wujud rasa tanggung jawab seorang suami kepada keluarga sehingga dengan demikian, bekerja merupakan suatu kewajiban syar'i bagi Ate. Hal lain yang tidak kalah kuatnya bagi seorang Ate, adalah untuk mandiri, tanpa ada ketergantungan kepada siapa pun, kecuali kepada diri dan Tuhan yang membagi rezeki kepada seluruh hambaNya. Oleh karena itu, dengan kuatnya motivasi ini, kendati Ate telah lama bekerja di perusahaan benang asing di Pasuruan dengan gaji dan fasilitas yang menggiurkan, ia tetap tekad untuk menyatakan keluar dan bermukim di Malang sampai akhirnya, membangun usaha bubur ayam seperti sekarang ini.

Motif lain yang tidak kalah mulianya adalah untuk menolong sesama dengan jalan memberi kesempatan kepada anak-anak muda bekerja di tempat usahanya. Dengan bekerja di sini kata Ate, mereka akan bertambah pengalaman, karena di samping banyak belajar, mereka juga akan mendapatkan gaji yang lumayan sebagai kompensasi dari tanggung jawabnya dalam melaksanakan kewajiban. 
Selain itu, ia membuka usaha adalah sebagai bagian dari sarana dakwah yang mengajak karyawannya untuk taat beribadah sesuai syariat, karena kalau tidak dengan sarana seperti ini kata Ate, kadangkala sulit mengajak orang untuk beribadah. Tapi jika ada ikatan antara atasan dan bawahan, maka niscaya akan ada memacam rasa sungkan untuk menolak himbauannya.

Hal lain yang ikut mendorong adalah membangun jaringan hubungan kemanusian, khususnya sesama Muslim yang dalam agama dikenal dengan istilah silaturrahim. Dengan bermitra melalui usaha, kata Ate, kita akan tambah saudara, di samping akan menguntungkan secara sosiologis atau kemanusiaan (hablum minannas), sekaligus juga sebagai sarana ibadah (hambum minallah). Karena menurut pandangan Ate yang namanya rezeki jangan hanya ditafsirkan dalam wujud uang (harta) semata, namun masih ada rezeki bentuk lain yang sangat tinggi nilainya, yakni eratnya silaturrahim. Baik dengan sesama karyawan yang sudah merasa dekat, maupun dengan para pelanggan, terutama pelanggan loyalis yang sudah pasti seringkali bertemu.

Dengan demikian apa yang telah dilakukan Ate pada prinsipnya telah menunaikan apa yang diajarkan agama sebagaimana telah dikemukakan di bagian lain sebelum ini.

\section{Strategi Pemasaran}

Dalam kaitan dengan strategi pemasaran yang diterapkan oleh "Abah Odil," adalah pemasaran sebagaimana umumnya. Antara lain menurut Ate, memasang iklan di koran (Malang Pos), majalah, banner, radio swasta dan sebagainya. Selain itu menurut Ate lebih lanjut, jika pelanggan yang sudah hapal (pelanggan lama/loyalis), mereka sudah tahu. Namun untuk customer yang baru, tentu perlu iklan. Dan hal ini perlu dilakukan secara terus menerus. Dengan demikian dalam melakukan pemasaran, Ate telah memanfaatkan instrumen teknologi yang berkembang sesuai zamannya (waqi'iyyah).

Selain itu dalam bentuk dari mulut ke mulut dari pihak owner sendiri dan para karyawan agar selalu mensosialisasikan kepada teman tetangga atau siapa pun saja yang memugkinkan untuk diberi informasi tentang usaha bubur ayam "Abah Odil." Demikian yang tidak kalah strategisnya informasi dari para pelanggan sendiri yang sudah merasakan menu bubur ayam ini. Sebab itu Ate, selalu 
berupaya untuk menjaga image/reputasi yang baik. Dengan mejaga reputasi, maka pelanggan akan secara otomatis akan ikut memberi informasi kepada orang lain karena rasa puas yang dialaminya sendiri.

Hanya saja menurut Ate yang perlu dijaga dalam pemasaran itu antara lain adalah tidak menipu, dalam arti harus jujur atau sama antara apa yang diiklankan dengan kenyataannya. Karena kalau tidak kata Ate, hilangnya kepercayaan (trust) masyarakat yang secara ekonomi akan merugikan perusahaan. Kalau rasa percaya telah ternodai kata Ate lebih lanjut, akan sulitlah kita mengembalikan kepercayaan itu dari para pelanggan. Dan hal ini akan terjadi dari mulut ke mulut di tengah masyarakat luas. Selain itu apabila kita menempuh cara pemasaran yang tidak benar sudah barang tentu berdosa, bagi setiap muslim yang merasa terikat dengan ajaran agama yang diyakininya. Ini berarti dalam melakukan pemasaran, Ate benar-benar telah memperhatikan aspek etis dan teistis

Lebih dari itu, di era perkembangan teknologi saat ini, Ate juga memanfaatkan jaringan internet untuk memasarkan produknya, sehingga pelanggan akan tahu akan keberadaannya. Terlebih lagi bagi bagi pelanggan yang jauh seperti dari komunitas mahasiswa luar negeri yang banyak menempuh studi di kota Malang. Karena itu dalam kaitan ini Ate berobsesi untuk membuka cabang di luar kota Malang, yang maksudnya untuk menambah jaringan agar lebih banyak dikenal oleh masyarakat luar kota.

\section{Pembinaan Sumberdaya Manusia}

Menurut pengakuan Prasetya, abah memiliki pribadi yang tegas, cekatan, dan mengutamakan ibadah. Biasanya jika sudah menjelang adzan, kata Yanti, para karyawan laki-laki diminta bersiapsiap untuk shalat berjemaah di masjid terdekat, seperti Masjid Ramadhan atau Muhajirin di kawasan perumahan Griyashanta. Tidak hanya itu menurut pengakuan Kamela, setiap minggu sekali ada pengajian rutin di masjid terdekat, dan para karyawan diwajibkan untuk mengikutinya.

Untuk lebih memperkuat tentang shalat itu, di sini peneliti akan mengemukakan sebuah realita, dimana pada suatu waktu peneliti mau membeli bubur ayam "Abah Odil," ternyata kantin itu ditutup padahal lampu masih tetap nyala, hanya saja setelah 
mencermati sekitar lokasi, ternyata ada tulisan "Maaf sedang shalat," untuk sementara belum melayani pembeli. Ini terjadi pada saat bulan puasa, sedangkan di hari-hari biasa biasanya dilakukan dengan sistem shift sehingga kantin tetap melayani pembeli. Oleh karena ada tradisi semacam ini, akahirnya perekrutan didahulukan yang muslim/musimah, kendati yang beragama lain pun tetap diterima seandainya mereka bersedia bekerja. Ini dimasudkan agar yang non muslim tetap bisa melayani pembeli, sementara yang muslim menunaikan shalat. Demikian penjelasan Ate.

Tidak hanya itu, untuk terus membina mental karyawan, "Abah Odil," sengaja memasang CCTV di lantai dua, dengan maksud untuk menguji mana karyawan yang bekerja dengan sungguhsungguh dan mana pula yang bekerja seadanya. Manurut penjelasan Ate, infrastruktur ini hanya sebatas untuk memberi efek psikologis para karyawan agar mereka merasa diawasi segala perilakunya dalam melaksanakan tugas kewajibannya. Dan saya sendiri merasa lebih tenang, tidak capek mengawasi secara kasat mata, kata Ate lagi. Tambah lagi sewaktu-waktu saya bisa memutar ulang CCTV itu untuk melakukan evaluasi secara menyeluruh tentang perilaku karyawan, tambah Ate lagi.

Selanjutnya penjelasan Prasetyo, "Abah Odil," biasa memberikan reward dan punishment yang diberikan secara personal. Reward diberikan kepada yang berprestasi sebagai kompensasi atas taggung jawab dalam mengemban amanah dengan baik. Sebaliknya, punishment dihadiahkan kepada yang melakukan. Hanya saja sebelum hukuman itu dijatuhkan, biasanya ada peringatan terlebih dulu sebanyak tiga kali. Jika masih tetap melakukan kembali, maka hukumannya biasanya diskors selama dua sampai tiga minggu. Beliau, sambung Prasetyo, tidak pernah memberhentikan, apalagi memecat para karyawannya. Apabila karyawan keluar, itu biasanya merupakan keinginan pribadi mereka sendiri.

Lebih jauh dalam membina karyawan dalam menjalankan tugas agar pelanggan tetap loyal adalah dengan terus melakukan kontrol terhadap kinerja karyawan dan kualitas rasa. Menekankan agar karyawan memberikan pelayanan prima kepada pelanggan sehingga pelanggan merasa nyaman. Sangat ditekankan agar karyawan melayani dengan baik dengan sapa, senyum, ucapan terima kasih kepada pelanggan. Pelanggan perlu diperlakukan secara 
maksimal, jangan cemberut. Harus ada komunikasi agar tidak hambar, sehingga pelanggan merasa diperhatikan. Kenali karakter pelanggan dan lakukan komunikasi. Katakanlah dengan jujur apa adanya kepada pelanggan dalam hal apa-pun.

Demikian cara Ate dalam membina karyawan, tidak bersifat diktator, namun bersifat kebapakan, dan mengayomi, bahkan senantiasa membimbing dengan hati nurani dan selalu mengajak karyawan agar selalu dekat dengan Penciptanya. Artinya, dalam membina sumberdaya manusia, ia tetap mengedepankan aspek insaniyyah dan akhlaqiyyah.

\section{Makna Kerja}

Ate membuka usaha mandiri yang penuh dengan rintangan dan tantangan. Rintangan dan tantangan itu memberi pelajaran berharga bagi Ate dalam memaknai usaha dan kerja untuk kepentingan dua dimensi sekaligus, yaitu keduniaan dan akhirat. Dalam hal ini dapat dipahami dari pernyataan Ate sendiri:

"Kerja bagi saya tidak lepas dari ibadah, menghidupi diri sendiri, anak istri dan ibadah menolong orang lain dalam bentuk memberikan lapangan pekerjaan bagi mereka. Jika bekerja hanya berharap gaji, maka berarti hanya mencari dunia saja. Tidak demikian, jika bekerja diniatkan ibadah, maka akan mendapatkan kedua-duanya." 40

Bagi Ate kerja seharusnya menjadi ibadah. Hal ini merupakan faktor utama menurut pemahaman Ate yang harus ditanamkan di lingkungannya. Sebagai salah seorang Muslim yang kukuh memegang teguh ajaran agama, Ate, menganjurkan agar karyawannya melaksanakan shalat tepat waktu di masjid terdekat. Ate tidaklah sekadar menganjurkan (verbal) semata, namun ia sendiri memberi contoh kepada orang-orang di sekelilingnya. Begitu terdengar bunyi adzan, Ate bergegas menuju masjid terdekat seperti masjid Ramadhan atau Al-Ghifari di lingkungan tempat usahanya.

Tidak hanya itu, Ate juga menghimbau kepada karyawannya agar mereka dalam seminggu sekali mengikuti pengajian dengan

40 Wawancara dengan Ate, 31 Juli 2015 
alasan agar mereka semakin dalam dan luas pengetahuan agamanya dan akan semakin dekat kepada Tuhannya. ${ }^{41}$

Hal itu diperkuat dari pengakuan salah seorang karyawan, Prasetyo, yang menyatakan:

"Memang Abah Odil mengajarkan kepada kami bahwa kerja itu merupakan ibadah dan beliau mempunyai prinsip agar owner mau memberi contoh langsung dan harus bertanggung jawab atas pembentukan moral spiritual karyawannya. Beliau mewajibkan karyawan shalat berjemaah, selalu memberikan tausiyah/nasehat, seminggu sekali ada pengajian dan bahkan melarang karyawan merokok. Karena itu ada tiga pilar yang selalu ditanamkan oleh beliau, yakni shalat berjemaah, tidak merokok, dan pengajian." 42

Tidak hanya itu, penjelasan lebih lanjut Prasetyo:

"Beliau selalu menghimbau kepada karyawan untuk melaksanakan shalat Dhuha, puasa Senin-Kamis, dan shalat Tahajjud. Karena itu semua adalah merupakan tanggung jawab beliau yang akan diminta pertanggung jawabannya nanti di akhirat. Beliau juga menjalin hubungan kerja dalam suasana kekeluargaan, bebas tapi terkendali, siapa pun dapat menduduki disini sebagai apa pun. Selain itu, karena kesibukan beliau, beliau memasang CCTV untuk memantau operasional kantin setiap harinya. Itu adalah sebagai salah satu pengendalian internal yang diterapkan beliau." 43

Inilah ibadah dan dakwah yang diterapkan Ate kepada para karyawannya. Apa yang diterapkan Ate ini, mempunyai arti positif dan memberikan kenyamanan bagi karyawannya. Hal tersebut dapat disimak dari pengakuan Prasetyo sendiri sebagai-berikut:

“Kebanyakan orang bekerja biasanya untuk mencari gaji, tapi bagi saya bekerja adalah bagian dari ibadah. Gaji, saya nomor duakan. Selama bekerja saya belum pernah mendapatkan tempat kerja yang memiliki sistem seperti ini, setiap minggu sekali ada pengajian dan wajib shalat berjemaah di masjid. Tapi dengan sistem yang seperti ini saya merasa senang, karena dapat meningkatkan aspek spiritual." 44

41 Disarikan dari hasil wawancara dengan Ate, 3 Agustus 2015

42 Wawancara dengan Prasetyo, 7 Agustus 2015

43 Wawancara dengan Prasetyo, 7 Agustus 2015

44 Wawancara dengan Prasetyo, 28 Agustus 2015 
Kerja bagi Ate memiliki makna kepedulian sosial. Kehidupan ini bukan semata tentang diri kita sendiri tetapi juga berhubungan dengan orang lain. Inilah nampaknya makna filantropis yang hendak dikembangkan dengan sungguh-sungguh oleh Ate dalam membuka usaha agar ia bisa berbagai kebahagiaan dengan orang lain. Dengan membuka lapangan kerja, maka ia telah berbagi dan menghidupi kebutuhan ekonomi orang-orang yang bekerja kepadanya. Kendati demikian, Ate selalu mengingatkan bahwa niat dalam bekerja adalah untuk ibadah agar dunia (harta) dan akhiratnya (pahala) sekaligus dapat diraih.

Ate sendiri bekerja tentu untuk memperoleh profit, karena dengan profit itu ia akan dapat menunaikan kewajiban memenuhi kebutuhan diri dan keluarganya. Ini semua tentu mempuyai makna ekonomi yang harus diterjemahkan dan diaktualisasikan kedalam bentuk usaha dengan kerja keras. Hal tersebut telah dilakukan oleh Ate dengan membuka usaha bubur ayam Tasikmalaya "Abah Odil."

\section{Kesimpulan}

Dari beberapa uraian di atas dapat disimpulkan bahwa usaha bubur ayam Tasikmalaya "Abah Odil" dibangun oleh pemiliknya di atas semangat kemandirian dan kerja keras. Motif spiritualitas dan hobbi yang diaktualisasikan dalam bentuk usaha untuk memenuhi kebutuhan diri beserta keluarganya, juga membentuk kisah sukses usaha tersebut.

Selanjutnya, dalam kaitan dengan strategi pemasaran, ditempuh cara dengan memasang iklan, melebarkan sayap usaha dengan membuka cabang baru, gethuk tular, dan promosi tidak langsung. Tidak jarang, Ate seringkali menghadiri berbagai pertemuan ilmiah, menjadi pembicara bersamaan dengan pengusahapengusaha lain. Selain pula dengan cara membuka cabang usaha di tempat yang dianggap strategis. Promosi dari lisan ke lisan juga dilakukan oleh para pelanggan setianya.

Adapun dalam kaitan dengan masalah pengembangan sumberdaya manusia, Ate menempatkan dan memperlakukan para karyawannya secara manusiawi. Ia juga mengedepankan nilai-nilai terpuji, terbuka, dan menanamkan toleransi yang tinggi terhadap pemeluk agama lain. 
Pemilik usaha bubur ayam Abah Odil memberi makna kerja yang pada dasarnya dapat dipetakan ke dalam lima aspek, yakni ibadah, ekonomi, silaturrahmi, pendidikan, dan dakwah. Kerja bernilai ibadah dimaksudkan untuk menunaikan kewajiban mencari nafkah yang halal. Sedangkan nilai ekonomi tentu untuk mendapatkan profit sebagai syarat kelangsungan usaha demi penghidupan sehari-hari. Adapun aspek silaturrahim adalah untuk mempererat persaudaraan sesama Muslim melalui kegiatan usaha.

Sedangkan kerja bernilai pendidikan, usaha yang didirikan Ate diorientasikan untuk memberikan pengalaman secara riil kepada anak-anak muda yang dipekerjakan agar kelak pada saatnya mereka mampu berwirausaha secara mandiri dan sesuai tuntanan agama. Sebab itu Ate menanamkan nilai-nilai pendidikan usaha yang berkebajikan dengan nuansa Islami seperti nilai kejujuran, keramahan, dan kecepatan serta ketepatan dalam pelayanan; menjaga kualitas produk dan lain sebagainya.

\section{Daftar Pustaka}

Afzalurrahman. Muhammad sebagai Seorang Pedagang, terj. Dewi Nurjulianti, dkk. Jakarta: Penerbit Yayasan Swarna Bhumy, 1997 Ahmad, Mustaq. Etika Bisnis dalam Islam, terj. Samson Rahman. Jakarta: Pustaka Al-Kautsar, 2001.

Alma, H.Buchari. Kewirausahaan, Cet. IV. Bandung: Penerbit Alfabeta, 2002.

Departemen Agama RI. Al-Qur'an dan Terjemahnya. Jakarta: PT. Bumi Restu, 1982.

Ancok, Djamaludin dan Fuat Nashori Suroso. "Teori Kebutuhan Berprestasi Versi Al-Qur'an," dalam Djamaludin Ancok dan Fuat Nashori Suroso, Psikologi Islami. Yogyakarta: Pustaka Pelajar, 1994

Antonio, Muhammad Syafii, "Prophetic Values of Business and Management", Republika, Juni 2002

Antonio, Muhammad Syafii. Muhammad saw the Super Leader Super Manager. Jakarta: Prophetic Leadership and Management C entre, 2007

Bungin, Burhan. Analisis Data Penelitian Kualitatif. Jakarta: PT RajaGrafindo Persada, 2003 
Bygrave, William D. The Portable MBA Entrepreneurship. New York: John Willey \& Sons, Inc, 1995

Darmolono, Wasi. Winning Mindset Potret Otak Entrepreneur Sejati, Berpikir Cemerlang di Saat Terbelit Hutang Merilis Bisnis di Saat Kondisi Kritis. Yogyakarta: Nuha Qffset, 2009

Dawam, M. Ensiklopedi Al-Qur'an: Tafsir Sosial Berdasarkan Konsepkonsep Kunci. Jakarta: Paramadina, 1996

Deakins, David. Entrepreneurship and Small Firms. London: The McGraw-Hill Companies, 1996

Dhavamony, Mariasusai. Fenomenologi Agama, terj. A. Sudiaraja, dkk. Yogyakarta: Penerbit Kanisius, 1995

Djakfar, Muammad. Agama, Etika, dan Ekonomi, Wacana Menuju Pengembangan Ekonomi Rabbaniyah. Malang: UIN-Malang Press, 2007

-------. Anatomi Perilaku Bisnis Dialektika Etika dengan Realitas. Malang: UIN-Malang Press, 2009

-------. Teologi Ekonomi Membumikan Titah Langit di Ranah Bisnis. Malang: UIN Maliki Press, 2010

-------. Etika Binis: Menangkap Spirit Titah Langit dan Pesan Moral Ajaran Bumi. Depok-Bogor: Penebar Plus, 2012

Effendy, Bahtiar. "Pertumbuhan Etos Kerja Kewirausahaan dan Etika Bisnis di Kalangan Muslim", dalam Bahtaiar Effendy, Masyarakat Agama dan Pluralisme Keagamaan. Yogyakarta: Galang Press, 2001

Fatchan, H.A. Metode Penelitian Kualitatif. Surabaya: Jenggala Pustaka Utama, 2011

Hisrich, Robert D. and Michael P. Peters. Entrepreneurship. Tokyo, Japan: Toppan Company Ltd., 1992

Kartajaya, Hermawa dan Muhammad Syakir Sula. Syariah Marketer. cet.2, Bandung: Penerbit Mizan, 2006

Meredith, Geoffry G., et.al. The Practice of Entrepreneurship. Begeva: International Labour Organization, 1986

Muh. Yunus. Islam \& Kewirausahaan Inovatif. Malang: UIN Malang Press, 2008

Najma, Siti. Bisnis Syariah dari Nol Langkah Jitu Menuju Kaya, Penuh Berkah dan Bermakna. Jakarta: Hikmah, 2008

Pandojo, Heidjrachman R. Wiraswasta Indonesia. Yogyakarta: BPFE, 1982 
Ritzer, George. Sosiology: A Multiple Paradigm Science. Terj. Alimandan. Jakarta: Rajawali Press, 1992

Schutz, Alfred. The Phenomenology of the Social World. American: Northwestern University, 1972

Sonhadji, H. Ahmad. Manusia, Teknologi, dan Pendidikan. Malang: UM Press, 2912

Suryana. Kewirausahaan Kiat dan Proses Menuju Sukses. Jakarta: Salemba Empat, 2013

Susanta, Gatut dan M. Azrin Syamsuddin. Cara Mudah Mendirikan UMKM. Depok: Raih Asa Sukses, 2009

Swasono, Sri-Edi. Menuju Entrepreneurial University, Bahan Seminar Sehari dalam Rangka Dies Natalis Universitas Brawijaya Malang ke 41, 29 Januari 2005

Undang-Undang Republik Indonesia Nomor 20 Tahun 2008 tentang Usaha Mikro, Kecil, dan Menengah

Weber, Max. Etika Protestan dan Semangat Kapitalisme. Terj. Yusup Priasudirja, Jakarta: Pustaka Prometha, 2003

Yunus, Yunus. Islam \& Kewirausahaan Inovatif. Malang: UIN Malang Press, 2008

Zimmerer, Thomas W. and Norman M. Scarborough. Essentials of Entrepreneurship and Small Busness Management, 2nd edition, New Jersy: Printice Hall, Inc Upper Sadle River, 1998 